\section{Britain's Energy Budget}

IN view of present controversy over the output of the coal industry, Mr. R. Bailey's article, "The Energy Perspective", in the Westminster Bank Review for February 1965 , is of special interest. Mr. Bailey discusses the relative contributions of coal and oil to Britain's energy budget, accepting the view that the needs for energy of the non-Communist world by 1985 would be more than doubled to reach the equivalent of $8,000-9,000$ million tons of coal, of which 49 per cent might be provided by oil and 18 per cent by natural gas, compared with 45 per cent and 15 per cont, respectively, to-day. Given a 4 per cent rate of growth for the economy, the total consumption of energy in the United Kingdom would rise from the 1962 level of 191 million tons of coal, 78.5 million tons of oil and natural gas, and 3.5 million tons of nuclear and hydroelectric power (or 273 million tons of coal equivalent in all) to totals of more than 300 million tons in 1966 and about 450 million tons of coal equivalent in 1980. Since it appears unlikely on its present showing that nuclear energy will make a significant addition to energy supplies at an economic price in the next 20 years, the bulk of the increase must come from the coal and oil industries. Under its present financial arrangements, the National Coal Board can break even on sales of 200 million tons a year, and marginal tonnage above this is produced very cheaply; hence the problem still remains as to where else a further 100 million tons of fuel can be obtained at $£ 2$ a ton. In searching for a policy to reconeile long-term and short-term considerations, Mr. Bailey points out that the quostions remain to be answered whether the coal industry should be encouraged to expand its output to a level nearer its primary eapacity and maintain it at that level as an insurance against future needs for energy. If this were accepted, how would oil, nuclear energy and natural gas be co-ordinated within this policy, and what part would the secondary fuel producers-gas and electricity-be expected to play, particularly in their selection of primary fuels? Mr. Bailey emphasizes that there are no immediate or short answers to these questions, and that, since Britain imports a quarter of her energy requirements, high priority must be given to maintaining economic production of her major indigenous fuel-coal. The secondary fuel industries of gas and electricity must not follow policies that endanger long-term supplies of tho primary fuels.

\section{British Overseas Research}

The Review of Colonial Research, 1940-1960, is edited by Sir Charles Jeffries for the Department of Technical Co-operation, and Lord Hailey contributes a foreword (Pp. 238. London: H.M.S.O., 1964. 21s.). It covers the developments and achievements in colonial research under the Colonial Research Committee and, later, tho Colonial Research Council until the functions of the latter Council were in 1959 transferred to the new Overseas Research Council, dissolved last year. There is also a brief review of earlier developments before the first Colonial Development and Welfare Act of 1940. The Survey is in two parts: a general record occupying about a quarter of the book, and a longer section in which various specialists provide more detailed summaries of progress in ten different broad fields-social science, economics, building and roads; health and medicine; agriculture; animal health; forestry; fisheries; plant and animal products; pesticides; locust research and control; and trypanosomiasis. The general record presents an impressive account, which deserves to be widely read, of a contribution to the welfare and development of the emerging countries, of which Britain can rightly be proud, and the details of which, as Lord Hailey observes, can be studied with advantage by those agencies whose mission it is to-day to improve the standards of life in the many underdeveloped countries.
That applies particularly to the new Ministry of Overseas Development, for the picture presented in this Survey does not indicate the extent to which the results of this expenditure of more than $£ 24$ million from 1940 onwards have been endangered by what has taken place since many of the territories achieved independence. It is not merely that interterritorial organizations have been endangered by lack of financial support; the failure of Britain to support the Overseas Research Council and its subsequent dissolution have also contributed, and while the general record and the specialist accounts indicate the opportunities and often illustrate the conditions required for success, they do not specifically refer to the recent shortcomings and failures which lie largely outside the period covered. Fssentially, the Survey as a whole summarizes, and presents in most readable form, information already published in the reports of the Colonial Research Council and the specialized advisory bodies which reported with it in Colonial Research. There is still needed a survey of the trends and developments since 1959 which the Overseas Research Council did not, or was not allowed to, provide. For all that omission, which the Ministry of Overseas Development might well be wise to rectify in some way later, the book should appeal both to the general reader and to the specialist. It could well stimulate not only a more general appreciation of what Britain has already done in this field but also an understanding and appreciation of the value of her overseas research effort which should ensure that support is forthcoming in future on the scale and in the ways required to make that effort increasingly effective.

\section{Tropical Pastures Research}

THE establishment of an International Tropical Grassland Commission is recommended in a resolution passed by the ninth International Grasslands Congress, held in São Paulo, Brazil, during January 7-21, 1965. In sponsoring the resolution, Prof. G. S. Puri (Kwame Nkrumah University of Science and Technology, Kumasi, Ghana) directed attention to the potential food and fodder production of the tropical grasslands. Their origin, and present status, result from shifting cultivation and fire. Although this type of land use is not ideal, it does represent the simplest means of releasing into the soil-plant system the nutrients that are locked up in plant material. Prof. Puri suggested that tropical pasture research should aim at breeding some drought-resistant perennial grasses and legumes to give material of a high leaf/stem ratio during the dry season. Physiological investigations should be directed towards prolonging the production of leafy material, and delaying flowering, in grasses and legumes, and towards reducing the rest period and activating the quick growth of leafy tissues. He pointed out that this work would involve research of a fundamental nature, to which plant physiologists in temperate parts of the world might be expected to contribute. Prof. Puri went on to advocate research into the utilization in husbanding of the tree pasturage, or woodland savannah, which covers so large an area in the tropics. He further suggested that since a satisfactory herbaceous perennial legume for tropical grasslands is not available, use should be made of some of the leguminous trees and shrubs. Tropical grasslands may be classified as 'reversible' or 'irreversible'. The former category comprises land in which trees and/or shrubs are invariably present, and which must therefore be managed on farm-forestry principles. 'Irreversible' grassland usually bears no trees, owing to shallow or waterlogged soil or other causes. They can and should be mechanized, especially as their management as natural grasslands is uneconomic. These types of grassland overlap the savannah types, and Prof. Puri urged that the savannah research section of the Food and Agriculture Organization should undertake the furtherance of this research and the establishment and maintenance of the Commission. 